\title{
Going public with notes on close cousins, food sovereignty, and dignity
}

\section{FoodDignity}

\author{
Philip McMichael a \\ Cornell University
}

with

Christine M. Porter $\mathrm{b} *$

University of Wyoming

Submitted April 30, 2018 / Published online July 18, 2018

Citation: McMichael, P., \& Porter, C. M. (2018). Going public with notes on close cousins, food sovereignty, and food dignity. Journal of A griculture, F ood Systems, and Community D evelopment, 8(Supp. 1), 207-212.

https:/ / doi.org/ 10.5304/ jafscd.2018.08A.015

Copyright ( 2018 by the Authors. Published by the Lyson Center for Civic Agriculture and Food Systems. Open access under CC BY license.

\section{Introduction}

In fall 2009, I taught a graduate course at Cornell University in the sociology of food and ecology. My students and I were fortunate to have food systems sociologist Harriet Friedmann participating in our seminar meetings while she was on sabbatical at Cornell. Twenty years earlier, Harriet and I had published a paper that sketched a framework characterizing political-economic epochs in global agriculture since 1870. We named these epochs "food regimes" (Friedmann \& McMichael, 1989). Christine Porter was a student

a Philip McMichael, Professor, D epartment of D evelopment Sociology, Cornell University; pdm1@ cornell.edu

$\mathrm{b} *$ C orresponding author: Christine M. Porter, Associate Professor and Wyoming Excellence Chair of Community and Public Health; Food Dignity Principal Investigator; Division of Kinesiology \& Health, College of Health Sciences, University of Wyoming; 1000 East University Avenue, D epartment 3196; Laramie, WY 82071 USA; christine.porter@ uwyo.edu in that course. She claims it helped her put enough academic and activist pieces of the food system puzzle together to propose what later became Food Dignity- a five-year action and research project about food security, sustainability, and sovereignty involving four higher education institutions and five community-based organizations doing food justice work in the U.S.

D uring that course, Christine and I remember Harriet mentioning that she searches for daisies breaking through the concrete of an industrialized, globalized food system, and also that I expressed a touch of envy about the hopefulness such sights might offer. From the standpoint of the international food sovereignty movement with which I

\section{Funding Disclosure}

Food Dignity (http:/ / www.fooddignity.org) was supported by Agriculture and Food Research Initiative Competitive G rant no. 2011-68004-30074 from the U.S. D epartment of Agriculture's National Institute of Food and Agriculture. 
work--a movement that opposes corporate power in the global food regime and its intensifying land grab across the world (McMichael, 2012)-- the flowers are certainly emerging.

In the spring of 2010, when Christine asked me to become a co-investigator in Food D ignity, she promised me proximity to daisies. Eight years later, at the very end of that project, I complied with her request for a concise essay. For this special issue, she asked me to help contextualize Food Dignity work within the international food sovereignty movement. I gave her a draft, which she edited, packed into the section below, and surrounded with additional passages aiming to help contextualize me and my work. Some she drafted herself, and others she lifted from my words shared within the context of the project collaboration. She proposed that she could be my "shadow co-author." For a third time, I have complied with her requests. Thus, here, I bookend the commentary Christine asked for with some personal reflections on my work within the context of Food Dignity.

I introduced myself and my food sovereignty work to the larger Food D ignity team during our first meeting in May 2011, which took place in Ithaca, New Y ork. I recall the leader of one of the partnering community-based food justice organizations, Jemila Sequeira of Whole Community Project, replying, "food sovereignty is a cousin of food dignity, as we understand it here." For reasons I outline below, I agreed with her.

In the first few years of Food D ignity, my project role waxed, as I tried to help figure out ways of building a community advisory board that would shape and monitor our plans for partnering with community activists on an engaged learning adventure. O ur plans centered on developing a just local food systems and an undergraduate minor in that arena at Cornell. Then I was press-ganged into chairing my department for two inconvenient years, and I found my Food Dignity role waning. For example, even though the May 2014 annual team meeting location was again in Ithaca, where I live, I was barely present. Compounding the weight of department head duties, I was facing family health issues, including ones that affected my own body. D ue to inheriting polycystic kidney disease, my kidneys were failing. I will return to that in my closing. First, here is the essay that Christine originally requested, contextualizing work of the five U.S. community-based organizations who partnered in the Food Dignity project within the larger international food sovereignty movement.

\section{Food Dignity and Food Sovereignty}

Food sovereignty is now a worldwide movement involving and embracing both rural and urban communities and building partnerships between them. The phrase originated in Mexico in the 1980s, when that country had a credible national food system that centered on a maize culture embedded in the ejido system of communal lands, which arose from the early $20^{\text {th }}$ century Revolution (Perramond, 2008). Then, in 1996, food sovereignty became a global rallying cry when the 200million strong international peasant coalition, $\mathrm{La}$ Vía Campesina, introduced the concept at the World Food Summit (Wittman, D esmarais, \& Wiebe, 2010). The aim was to politicize the neoliberal order institutionalized in the World Trade O rganization's Agreement on Agriculture. This Agreement was geared toward opening farm sectors across the global South to food dumping in their local markets, primarily by the U.S. and the European Union. Rather than buying into the empty claim of "feeding the world" via private trade organized by transnational corporations in the name of food security, La Vía Campesina demanded national policies of food sovereignty to protect and enhance domestic farming systems. In addition to deploying sovereignty to resuscitate small-scale farming as a public resource for food security and nutrition, the term demanded democratization of community and regional food systems. This democratization includes respecting the right to food and the land rights of small- and mediumscale farmers to produce food (as opposed to the neoliberal right to purchase food in the market). It also includes gender equity in land rights, farm labor rights, and territorial rights for indigenous peoples.

As a claim, the ethical goals of food sovereignty have inspired mobilizations globally, including demanding land rights, saving and sharing seeds (as opposed to corporate patenting 
of commercial seeds), occupying unused land for food production (as opposed to speculation), creating training schools for agro-ecological farming methods, forming farmers markets so producers can sell directly to eaters, and rehabilitating land. Local food system actors and organizations are doing these kinds of food sovereignty work and more on all inhabited continents. For example, Brazil, under President Lula's Anti-Hunger Campaign, purchased staple grains from the Landless Workers Movement (as it occupied unused land) for redistribution to the poor (Wittman \& Blesh, 2017). Another model project is the southern Brazilian city Belo Horizonte, which has forged a close relationship with adjacent farming systems to provide food for public institutions in a mutually beneficial partnership between farmers and citizens (Rocha \& Lessa, 2009).

Food sovereignty strategies such as these emerge, repeat, and unfold in communities across the world, including as devised and carried out by community-based food justice organizations in the U.S., such as the five who partnered in Food D ignity. Here is just one example from each. Blue Mountain Associates in Wind River Indian Reservation founded the first tribal farmers market in that area. Feeding Laramie Valley, in Laramie, Wyoming, grows food on city and county public lands to share with (not sell to) the Albany County community. Dig D eep Farms, in unincorporated Ashland and Cherryland near $\mathrm{O}$ akland, California, employs people who have previously been incarcerated as urban farmers. Whole Community Project provided enabling support to community leaders across Tompkins County, New Y ork, to grow food in parks, yards, community farms, senior housing, and public housing communities. East New York Farms! in Brooklyn, New York, supports community members in growing and selling culturally important foods using sustainable growing practices, such as cover cropping.

People and community organizations leading these kinds of food efforts, especially in the Global South, have carried their sovereignty ideals to political and economic elites in Rome, at the United Nation's (UN) Food and Agricultural Organization (FAO). To organize the first nongovernmental organization forum that ran parallel to FAO's World Food Summit in 1996, La Via Campesina and others established an "ad hoc" committee called the International Planning Committee for Food Sovereignty (IPC), with representatives from the front lines of world hunger and local food provisioning (Nyéléni, 2007). Since 2002, they have organized civil society summits in parallel to the FOA World Food Summits every year. The IPC has matured to a global network of over 150 chapters in at least 70 countries (International Planning Committee for Food Sovereignty, 2009). It has successfully pushed the FAO to step up as the UN agency responsible for food security and nutrition rights and to give civil society access to the debates in the UN's Committee on World Food Security (CFS) via a newly created Civil Society Mechanism (Committee on World Food Security, 2010; see also http:// www.csm4cfs.org). I was invited to join the Civil Society Mechanism as one of a handful of academics who provide moral support and mental labor to the civil society groups. As such, I was tasked with helping prepare documents to support positions the Mechanism takes in the CFS debates as well as meeting with government delegates to advocate Mechanism debate positions. For example, one task I had was as a member of a two-year technical support team on the question of responsible investment in agriculture. This was in the context of the World Bank's attempt to define (and enclose) principles enabling large-scale financial investment in land offshore (McMichael \& Müller, 2014).

A multitude of constituencies are represented in the FAO's Committee on World Food Security forum through this Civil Society Mechanism. Policy debates and reports on the multifunctionality of food and agriculture now include the voices of those on the ground rather than simply those of public servants and corporates. These voices included those of social movements such as La Vía Campesina and other organizations representing fisherfolk, pastoralists, farm workers, and indigenous people. They also include progressive nongovernmental organizations such as G lobal Witness, Focus on the Global South, and Oxfam. The representatives in the Civil Society Mechanism do not have formal voting powers, and they don't 
want them. They insist on maintaining their autonomy from the formal structures of the member states so they can maintain whatever moral pressure they can bring to bear on governments regarding domestic food security and nutrition issues.

The CFS also now includes an advisory group to review scientific evidence and make evidencebased policy recommendations on global food security. This group, named the High-Level Panel of Experts, is composed of academics, policymakers, and practitioners. Its 2013 report, Investing in Smallholder A griculture for F ood Security, is, in my view, among its most important to date. In the context of land-grabbing - with large offshore financial investments in land for food and fuel supplies for global markets, and for states that also mobilize investment funds for their own future food security- the CFS hosted a long debate about what responsible investment in agriculture should look like. In the context of arguments made by civil society members, the Panel argued that the majority of investments in agriculture are made by small-scale farmers via their labor and seed- and knowledge-sharing across farming communities. It concludes: "smallholder agriculture is the foundation of food security in many countries and an important part of the social/ economic/ ecological landscape in all countries" (High-Level Panel of Experts, 2013, p. 11). In addition to cautioning against financial investment by non-agricultural private interests, the panel's claim resonates with the home and community food production work that the five food justice organizations that partnered in the Food Dignity project support in their communities (Porter, 2018). With parallels to the high productivity of home gardens identified in a Food Dignity research project by Feeding Laramie Valley and Christine (Conk \& Porter, 2016), the report also notes that productivity rates are higher on smallholder farm polycultures than on larger commercial farm monocultures.

In addition, the report notes that, in contrast to commercial financial investments in agriculture- which seek only profit- in smallholder farms, the families doing the farming are the main investors. These smallholder investors seek to yield at least a partial living for their families; they also seek improved soil, seeds, tools, water cycles and other nonmonetized and multifunctional goods. For example, "smallholder's families are part of social networks within which mutual assistance and reciprocity translate into collective investments (mainly through work exchanges) and into solidarity systems" (High Level Panel of Experts, 2013, pp. 10-11). ${ }^{1}$

Accordingly, the most grassroots and justiceoriented arms of the food movement in the U.S. are at least first cousins of food sovereignty, and particularly so as they increasingly embrace sovereignty and justice concerns of indigenous and minority groups. However, though there are some direct links between the U.S. movement and the international one (see, e.g., the U.S. Food Sovereignty Alliance and the Coalition of Immokalee Workers), both movements can benefit from more intentional solidarity between them, especially in achieving national and international policy goals.

\section{Interpersonal Solidanity}

In their food justice work, Blue Mountain Associates, Feeding Laramie Valley, Dig D eep Farms, Whole Community Project, and East New York Farms! all strive to establish community forms of solidary, including in sharing resources (Hargraves et al., 2017). In addition, in ways outlined in our project values statement (Hargraves, 2018), the people and organizations that came together for over five years to collaborate on the Food Dignity project were also striving for some form of solidarity.

In May 2013, before I assumed department head duties at Cornell, I was part of our Food Dignity team meeting held in Laramie, Wyoming. Christine was there too, and in between chemotherapy and mastectomy treatments for her breast cancer. Inspired by the public way in which she was confronting her own health issue, I confided in her about my own health fears relating to my kidney function being in decline. Then I learned more about the Crohn's disease struggle of one of our collaborators in the Whole Community Project,

1 I served as one of the many external peer reviewers for this report (see http:/ / www.fao.org/ fsnforum/ member/ philipmcmichael). 
Journal of Agriculture, Food Systems, and Community Development

ISSN: 2152-0801 online

https:/ / www.foodsystemsjournal.org

Damon Brangman, who shared his journey to healing in dignity and strength through food not only with the team, but with the world (Brangman, 2015). The courage and resilience Christine and Damon showed helped me come to terms with my own health, as did seeing how their comrades took it in stride with acceptance and much caring. Their examples helped to guide and reassure me when, in order to seek a kidney donor, I needed to go public with my own health issue. In 2017, a wonderful human shared one of their kidneys with me, giving me a new lease on life.
I have spent the past decades studying and supporting solidarity within the agricultural struggles of peasant and other smallholders that have become the international food sovereignty movement. However, the opportunity to work so closely with dozens of people from five communities in this country who are breaking through concrete with food and myriad forms of metaphorical flowers, for me, has revealed a new, elemental dimension to community-building that fosters a precious humanity, even as we struggle.

\section{Referenoes}

Brangman, D . (Producer). (2015). Fruits and roots [Video] Retrieved from https:// www.youtube.com/ watch?v=9L rrofUG 2KA

Committee on World Food Security. (2010). Proposal for an international food security and nutrition divil sodedy mechanism for relations with CFS (C ommittee on W orld F ood Searity) - status report. Rome: Food and Agriculture O rganization of the United Nations (FAO). Retreived from http:// www.fao.org/ docrep/ meeting/ 019/ k8933e.pdf

Conk, S. J., \& Porter, C. M. (2016). Food gardeners' productivity in Laramie, Wyoming: More than a hobby. A merican Journal of Public H ealth, 106(5), 854-856. https:/ / doi.org/ 10.2105/ AJPH.2016.303108

Friedmann, H., \& McMichael, P. (1989). Agriculture and the state system: The rise and decline of national agricultures, 1870 to the present. Sodiologia Ruralis, 29(2), 93-117. https:// doi.org/ 10.1111/ j.1467-9523.1989.tb00360.x

Hargraves, M. (2018). Introduction to the Food Dignity values statement. Journal of A griculture, Food Systems, and Community D evelopment, 8(Suppl. 1), 33-35. https:// doi.org/ 10.5304/jafscd.2018.08A.018

Hargraves, M., D enning, C., BMA, DD F, ENY F, FLV, \& WCP. (2017). Food D ignity C ollaborative Pathway M odels. Retrieved from https:/ / www.fooddignity.org/ collaborative-pathway-models

High Level Panel of Experts. (2013). Investing in smallholder agriculture for food security. Rome: Food and Agriculture Organization of the United Nations (FAO). Retrieved from http:/ / www.fao.org/ fileadmin/ user_upload/hlpe/ hlpe documents/HLPE_Reports/ HLPE-Report$\underline{6 \text { Investing_in smallholder agriculture.pdf }}$

International Planning Committee for Food Sovereignty. (2009). D edaration from social movements/ N G 0 s/ C S0 s. Rome: Food and Agriculture O rganization of the United Nations (FAO). Retrieved from http:/ / www.fao.org/ fileadmin/ templates/ wsfs/ Summit/ CSO docs/ Final D eclaration-EN.pdf

McMichael, P. (2012). The land grab and corporate food regime restructuring. The Journal of Peasant Studies, 39(3-4), 681701. https:/ / doi.org/ 10.1080/ 03066150.2012.661369

McMichael, P., \& Müller, B. (2014, September 19). The land-grab trap: Is there a will to govern global land grabbing? Focaal Blog, of Focaal: Journal of $\mathrm{G}$ lobal and $\mathrm{H}$ istorical A nthropology. Retrieved from http:/ / www.focaalblog.com/ 2014/ 09/ 19/ philip-mcmichael-birgit-muller-the-land-grab-trap-is-there-a-will-togovern-global-land-grabbing/ \#sthash.EleCw1IY.dpuf

Nyéléni. (2007). IPC for food sovereignty. Retrieved from https:// nyeleni.org/ spip.php?article71

Perramond, E. P. (2008). The rise, fall, and reconfiguration of the Mexican ejido. G eographical Review, 98(3), 356-371. https:// doi.org/ 10.1111/j.1931-0846.2008.tb00306.x

Porter, C. M. (2018). G rowing our own: Characterizing food production strategies with five US community-based food justice organizations. Journal of A griculture, F ood Systems, and Community D evelopment, 8(Suppl. 1), 167-185. https:// doi.org/ 10.5304/ jafscd.2018.08A.001

Rocha, C., \& Lessa, I. (2009). Urban governance for food security: The alternative food system in Belo Horizonte, Brazil. International Planning Studies, 14(4), 389-400. https:// doi.org/ 10.1080/ 13563471003642787 
Wittman, H., \& Blesh, J. (2017). Food sovereignty and F ome Z ero: Connecting public food procurement programmes to sustainable rural development in Brazil. Journal of A grarian C hange, 17(1), 81-105. https:/ / doi.org/ 10.1111/joac.12131

Wittman, H., Desmarais, A., \& Wiebe, N. (2010). The origins and potential of food sovereignty. In H. Wittman, A. D esmarais, \& N. Wiebe (Eds.), F ood sovereignty: Reconnecting food, nature and community (pp. 1-14). 0 akland, CA: Food First. 